\title{
Asbestos in Schools and the Economic Loss Doctrine
}

For several decades in the middle of this century, contractors made extensive use of asbestos as an insulating and structural material. Recognizing its dangerous properties, building owners have recently begun attempting to recover from asbestos manufacturers the costs incurred for abatement or removal. ${ }^{1}$ School boards have been prominent in these attempts, as asbestos was widely used in school buildings.

These actions differ from personal injury claims involving asbestos in that the compensation sought is for "economic loss"-that is, for the cost of removing and replacing the asbestos itself. Losses of this sort, which are due to the selection of a product that is inferior or inappropriate, are normally remediable only through a warranty action. ${ }^{2}$ By contrast, harm to a person, or to property other than the product itself, is usually remedied by a tort action. ${ }^{3}$

1 The magnitude of the problem is enormous and growing rapidly. In re School Asbestos Litigation, 789 F.2d 996, 1000 (3d Cir. 1986). Of approximately 14,000 of the nation's schools containing friable asbestos (a crumbly form of asbestos that easily releases fibers into the air), 8,500 have an abatement problem. See Philip Shabecoff, New Data Find Asbestos A Peril in Home, at Job, N.Y. Times A1, col. 5, D23, col. 1 (Aug. 7, 1984) (recent EPA report finds some 31,000 schools containing asbestos). Although "the claims currently pending represent only a small percentage of the total number of potential claimants, the amounts involved are already staggering." Lac D'Amiante du Quebec v. American Home Assurance Co., 613 F.Supp. 1549, 1551 (D.N.J. 1985). Johns-Manville, a Denver-based paper and building products corporation, alone faced $\$ 86$ billion in property damage claims as of February, 1986, and filed for bankruptcy after being flooded with more than 16,000 lawsuits by asbestos claimants. Tamar Lewin, A New Set of Hurdles for Manville, N.Y. Times D1, col. 3, D3, col. 1 (Feb. 17, 1986). This figure was up from $\$ 69$ billion in June of 1985, School Asbestos Litigation, 789 F.2d at 1000, and from approximately $\$ 1$ billion in January of 1985 . See Jonathon Dahl, Flurry of Claims Against Manville Exceeds $\$ 1$ Billion, Wall St. J. 3, col. 3 (Jan. 31, 1985).

2 See, e.g., Borel v. Fibreboard Paper Products Corp., 493 F.2d 1076 (5th Cir. 1973) (claim against manufacturer for breach of duty to warn of dangers involved in handling asbestos); Note, Economic Losses and Strict Products Liability: A Record of Judicial Confusion Between Contract and Tort, 54 Notre Dame Lawyer 118 (1978) (brief overview of theoretical framework).

3 The scope of the theory of strict liability in tort is set out in the Restatement (Second) of Torts § 402A (1965) ("Restatement"), which provides:

(1) One who sells any product in a defective condition unreasonably dangerous to the user or consumer or to his property is subject to liability for physical harm thereby 
Despite this traditional distinction, most courts faced with claims of economic loss from asbestos abatement or removal have analyzed the claims in tort. ${ }^{4}$ This comment explains the economic distortion caused by the tort approach and illustrates how a contract analysis provides adequate protection for purchasers while preserving free market incentives to minimize the costs of loss prevention. ${ }^{5}$ More specifically, the comment analyzes one of the central issues arising in attempts by school boards ${ }^{6}$ to recover removal

caused to the ultimate user or consumer, or to his property, if

(a) the seller is engaged in the business of selling such a product, and

(b) it is expected to and does reach the user or consumer without substantial change in the condition in which it is sold.

(2) The rule stated in Subsection (1) applies although

(a) the seller has exercised all possible care in the preparation and sale of his product, and

(b) the user or consumer has not bought the product from or entered into any contractual relation with the seller.

(Emphasis added.)

Strict liability under section 402A, then, only remedies physical harm. Similarly, section 395 ("Negligent Manufacture of Chattel Dangerous Unless Carefully Made") contemplates only "liability for physical harm." See, e.g., Posttape Assocs. v. Eastman Kodak Co., 537 F.2d 751, 755 (3d Cir. 1976); Arizona v. Cook Paint and Varnish Co., 391 F.Supp. 962, 971 n.10 (D. Ariz. 1975). Compare the scope of sales warranty set out in $\$ \S 2-714$ and 2-715 of the Uniform Commercial Code ("UCC"), which allows for buyer's recovery of:

(a) any loss resulting from general or particular requirements and needs of which the seller at the time of contracting had reason to know and which could not reasonably be prevented by cover or otherwise; and

(b) injury to person or property proximately resulting from any breach of warranty. UCC 2-715(2). No limitation to physical harm is present. See generally E. Allan Farnsworth, Contracts $\$ 12.8$ (1982); Note, 54 Notre Dame Lawyer 118 (cited in note 2).

4 See, e.g., Adams-Arapahoe School District No. 28-J v. Celotex Corp., 637 F.Supp. 1207 (D. Colo. 1986); City of Manchester v. National Gypsum Co., 637 F.Supp. 646 (D. R.I. 1986); Town of Hooksett School District v. W.R. Grace \& Co., 617 F.Supp. 126 (D. N.H. 1984); Cinnaminson Township Board of Education v. U.S. Gypsum Co., 552 F.Supp. 855 (D. N.J. 1982). Compare City of Greenville v. W.R. Grace \& Co., 640 F.Supp. 559 (D. S.C. 1986) (municipality sued for costs of removal and replacement of fireproofing in city hall that contained asbestos); Philadelphia National Bank v. Dow Chemical Co., 605 F.Supp. 60 (E.D. $\mathrm{Pa}$. 1985) (costs of removing and replacing of an inferior construction product from building sought on basis of structural defects rather than carcinogenic danger).

B The importance of maintaining the distinction between tort and contract law has recently been emphasized by the Supreme Court in its handling of the doctrine of economic loss in the only area in which there is a federal common law of torts-admiralty. See East River S.S. Corp. v. Transamerica Delaval, 106 S.Ct. 2295, 2302 (1986) ("The minority view [rejecting the economic loss doctrine] fails to account for the need to keep products liability and contract law in separate spheres and to maintain a realistic limitation on damages.").

- Though this comment focuses on school buildings, there seems no reason why the same analysis should not apply to all buildings containing asbestos materials. See School Asbestos Litigation, 789 F.2d at 1005, where the Third Circuit, in refusing to approve certification of a mandatory class for punitive damages, found that the class comprising schools claiming asbestos related losses is underinclusive as it "[does] not . . . include all property damage claimants. Claims for repair of municipal buildings, for instance, are omitted, as are 
and replacement costs from asbestos manufacturers in tort: the characterization of this damage as physical harm.

Part I explains the legal and factual background underlying the problem of recovery for abatement and removal costs relating to asbestos. It concludes that, because of the statutes of limitations involved, most school boards stand no chance of recovery unless their claims are actionable in tort. Part II therefore examines the range of accepted views on what damages may properly be recovered in tort, as opposed to warranty. This section employs an economic analysis that justifies treating economic loss differently from physical harm, and that supports a distinguishing test based on the suddenness and dangerousness of the defect in question.

Part III discusses the application of the sudden and dangerous test in deciding the school boards' claims. It concludes that, while certain elements of their claims relating to the contamination of collateral property arguably may be claims for physical harm, the costs of removal and replacement of the asbestos materials themselves must be considered economic loss and therefore not recoverable in tort. Social policy considerations also support this conclusion. Because many asbestos manufacturers have been reorganized or are facing reorganization under Chapter 11 of the Bankruptcy Code, they are now effectively owned by asbestos personal injury claimants. If school boards are allowed tort recovery against such manufacturers, compensation will ultimately come out of the pockets of victims of asbestos-related diseases.

\section{Background and Definition of the Problem}

\section{A. Historical and Statutory Developments}

Asbestos is the generic name for naturally occurring minerals that separate into fiber. ${ }^{7}$ Because asbestos is fire resistant, pos-

those of homeowners."

An attempt to distinguish school buildings from other buildings might focus on the fact that public school students may not choose the particular school they will attend and so constitute a class deserving of special protection by the courts. The schools might claim that even if abatement procedures are economic loss, allowing them to recover will protect a helpless class of school children who are both unable to protect themselves and legally required to attend school. For other somewhat strained attempts to justify special treatment for schools, see U.S. Dept. of Justice, The Attorney General's Asbestos Liability Report to Congress 110, 155 (Sept. 21, 1981) ("1981 Attorney General's Report").

' See Office of Pesticides and Toxic Substances, United States Environmental Protection Agency, Guidance for Controlling Friable Asbestos-Containing Materials in Buildings 2-1 (1983) ("1983 EPA Study"); NIOSH-OSHA Asbestos Work Group, Workplace Exposure to Asbestos, Review and Recommendations 10 (1980) ("1980 NIOSH Study"). "Arguments 
sesses good tensile strength, and insulates well against heat and electricity, it came into common use as a building material around the middle of this century. ${ }^{8}$ In the 1970 s, however, the EPA banned spray-on asbestos materials because of concern over higher rates of asbestosis and cancer observed in individuals whose occupations entailed exposure to asbestos fibers. ${ }^{9}$

Since 1982, the EPA has required school districts to conduct inspections to determine whether their buildings contain asbestos materials. ${ }^{10}$ But these requirements have not had a practical effect, because no guidelines have been established to determine when the hazard is sufficient to justify removal or abatement. ${ }^{11}$ Under the

can be made for inclusion of all fibrous minerals posing risks comparable to commercially exploited minerals called asbestos. However, a practical definition would only include those mineral forms commonly used commercially: chrysotile, crocidolite, amosite, tremolite, actinolite, and anthophyllite." 1980 NIOSH Study at 10-11.

There is considerable evidence that the various forms of asbestos possess differing pathenogenic properties. See Oversight Hearings on Asbestos Hazards in Elementary and Secondary Schools, Subcomm. on Elem., Secondary, and Vocational Educ. of the House Comm. on Educ. and Labor, 98th Cong., 1st Sess. 109 (Apr. 27, 1983) ("1983 Oversight Hearings") (reporting that the kind of asbestos used in schools is chrysotile, which is by far the least dangerous); M. David Logan, Extent of Asbestos Danger Is International Disagreement, Occupational Health and Safety Magazine 63 (Jan. 1986); Pamela Zurer, Asbestos: The Fiber That's Panicking America, Chemical and Engineering News 28, 34-35 (Mar. 4, 1985) (importance of fiber length). But see 1980 NIOSH Study at 2 (cited in this note) (no basis for differentiating among fibers for regulatory purposes).

s See 1981 Attorney General's Report at 8-9 (cited in note 6); Asbestos School Hazard Detection and Control Act of 1980, Sen. Rep. No. 96-710 at 3 (May 15, 1980); 20 U.S.C. $\S 4011(a)(4)$ (1984).

In 1973, the EPA banned the spraying of asbestos for insulating and fireproofing. See 40 C.F.R. $\$ 61.22$ (e) (1973); 1983 Oversight Hearings at 34 (cited in note 7). In 1978, the EPA widened its restriction to include all spray applications for any purpose. 40 C.F.R. $\S 61.22(e)$ (1978). For current EPA asbestos rules, see 40 C.F.R. $\$ 61.148,61.150$ (1985). See also Francis J. Flaherty, Second Wave of Litigation Hits Asbestos, Nat'l L. J. 1, col. 1 (Oct. $29,1984)$. The EPA recently proposed a total ban on all asbestos products, to take effect within the next ten years. The primary remaining uses of asbestos are for cement pipe, coatings, friction products (brakes), packing and gaskets, and roofing products. Asbestos Users Step Up Search for Substitutes, Chem. Engin. Mag. 18, 19 (Oct. 27, 1986).

Human occupational exposures to all commercial asbestos fiber types, both individually and in various combinations, have been associated with elevated rates of asbestosis, a debilitating lung disease; lung cancer; and mesothelioma, a rare but invariably fatal cancer of the chest and abdominal lining. See, e.g., 1983 EPA Study at 1-1 (cited in note 7); 1980 NIOSH Study at 2,18,19, 24 (cited in note 7) (surveying many prior studies establishing the correlation); Bertrand v. Johns-Manville Sales Corp., 529 F.Supp. 539, 544 (D. Minn. 1982); 20 U.S.C. $\S 4011(a)(1)$.

1040 C.F.R. $\S 763.100$ (1985). See also Toxic Substance Control Act, 15 U.S.C. $\S 2605$ (1985).

11 See The Asbestos School Hazard Abatement Act of 1984, 20 U.S.C. § 4011(a)(8) (1984); Comment, Issues in School Asbestos Hazard Abatement Litigation, 16 St. Mary's L. J. 951, 955 \& n.14 (1985).

For criticisms of EPA's previous attempts to provide a reliable measure of hazards from 
Asbestos Hazard Emergency Act of 1986, the EPA is required by November, 1987 to promulgate regulations that specify inspection standards and appropriate responses. ${ }^{12}$ Even without such guidelines, most school districts undertake some form of abatement procedure if they discover asbestos in their school buildings. ${ }^{13}$ Thus, in many cases the question is not whether abatement will occur, but rather who will bear its costs.

Schools may seek funding for abatement under the Asbestos School Hazard Abatement Act of 1984 ("1984 Act"). ${ }^{14}$ This statute, an improvement on similar prior legislation, ${ }^{15}$ provides grants and low-interest loans for abatement procedures. ${ }^{16}$ But even the 1984

nonoccupational exposure, see Michael E. Findley et al., An Assessment of the Environmental Protection Agency's Asbestos Hazard Evaluation Algorithm, 73 Amer. J. Pub. Health 1179, 1180-81 (1983); Morton Corn, Asbestos and Disease: An Industrial Hygienist's Perspective, 47 Amer. Indus. Hygiene Assoc. J. 515, 520 (Sept. 1986) (EPA algorithm "can only be viewed as administrative arrogance bordering on 'chutzpah" "). The EPA's previous failures in this regard may be understandable in light of the scientific uncertainty relating to the dose/response curve of asbestos and the technical difficulties of measuring exposure levels. See, e.g., 1983 Oversight Hearings at 42 (cited in note 7) (statement of Edward A. Klein, Director, Chemical Control Division, Office of Toxic Substances, EPA).

${ }^{12}$ See, e.g., 51 Fed. Reg. 42812 (Nov. 25, 1986). The EPA must issue final rules pertaining to: 1) inspection of all school buildings for asbestos materials; 2) standards identifying circumstances requiring response; 3 ) descriptions of appropriate response actions; 4) implementation of those response actions; 5) establishment of monitoring programs; 6) preparation and implementation of asbestos management plans; 7) submission of those management plans to state governors; 8) the transportation and disposal of the removed asbestos; and 9) the development of model state accreditation programs for persons who perform inspections, prepare management plans, and work in asbestos abatement industry.

${ }^{13}$ Asbestos in Schools: Hearings Held on Adequacy of Federal Efforts to Control Asbestos Hazards, summarized in Andrews, Asbestos Litig. Rep. 9026, 9027 (Oct. 5, 1984) (two-thirds of schools with asbestos problems have taken corrective action or are in the process of taking corrective action).

14 20 U.S.C. $\$ \S 4011-4021$ (1984). In some instances a school district may not have access to funding for abatement without advance assistance. In these situations, the question may be not only who will bear the ultimate cost, but also when the abatement procedures will commence.

1820 U.S.C. $\$ 3601-3611$ (1980). Perhaps the most important difference between the 1980 Act and the 1984 Act is that the latter disburses money more generously. Compare 20 U.S.C. § 3605 (providing only loans for abatement and only up to 50 percent of the costs) with 20 U.S.C. $\S 4014$ (e) (providing loans for up to 100 percent of abatement costs, or a combination of loans and grants if an applicant is unable to undertake and complete an asbestos abatement program with a loan).

16 The 1984 Act is intended to "provide continuing scientific and technical assistance to State and local agencies to enable them to identify and abate asbestos hazards in schools" and to "provide financial assistance for the abatement of asbestos threats to the health and safety of school children or employees." 20 U.S.C. $\$ 4011(b)(2)$, (3). In addition to the federal program, some nineteen states have created parallel asbestos abatement funds to assist local schools in abatement. See Asbestos School Hazard Detection and Control Act: Hearings on H.R. 11 \& H.R. 4720, Subcomm. on Elem., Secondary, and Vocational Educ. of the House Comm. on Educ. and Labor, 98th Cong., 2d Sess. 19-20 (describing the plans of these 
Act may not satisfy the financial needs of afflicted schools. As an initial matter, the program established by the 1984 Act may be drastically underfunded. ${ }^{17}$ Furthermore, the EPA consistently has declined to request and disburse even the limited funds established by the 1984 Act. ${ }^{18}$ In addition to forcing schools into a lengthy administrative process, the 1984 Act may not provide any sort of assistance for some of the schools' losses, such as replacement costs for contaminated curtains or carpets. ${ }^{19}$

The inadequacy of the statutory response to schools' funding needs may drive schools to litigation. ${ }^{20}$ But even if the 1984 Act

nineteen states) ("1984 Asbestos Hearings").

17 The law provides for loans of up to 100 percent of the costs of abatement which are interest-free for twenty years. See 20 U.S.C. $\$ 4014(\mathrm{e})$, (f). If a loan is inadequate, the 1984 Act authorizes a grant that is not to exceed 50 percent of the total abatement cost. Id. at $\S 4014(e)(1)$. The loans and grants are based on financial need. Id. $\$ 4014(\mathrm{c})$, (d). The 1984 Act allocates a total of $\$ 500$ million over the five-year period from 1986 through 1990 . Id. at $\S 4021(a)(1)$.

Even with parallel state programs supplementing the federal fund, however, it seems highly unlikely that these resources alone will be sufficient to cover the billions of dollars required for abatement and removal. Some observers predict that the removal costs will total $\$ 1.4$ billion; this estimate is based on projections of 14,000 affected schools and removal costs of $\$ 100,000$ per school. See 1984 Asbestos Hearings at 23 (cited in note 16); Robert D. Lang, The Problem of Asbestos in the Public schools, N.Y. State Bar J. 20 (Nov. 1984). This projection appears to be overly optimistic. For an example of the actual options and costs available to one school, see Board of Education v. Ambach, 123 Misc.2d 622, 474 N.Y.S.2d 244 (Sup. Ct. 1984) (removal $(\$ 719,250)$, encapsulation $(\$ 239,400)$, containment $(\$ 304,500)$, combined encapsulation removal $(\$ 605,850))$. Extrapolating from similar figures, the abatement costs for public schools would total between $\$ 48$ and $\$ 54$ billion. 1984 Asbestos Hearings at 23 (cited in note 16).

18 The administration consistently failed to call for funding for the predecessor 1980 Act in the past. See 1984 Asbestos Hearings at 11 (cited in note 16). Both the 1987 and 1988 budgets provide only half of the $\$ 100$ million authorized. Office of Management and Budget, Appendix to Budget of the United States Government Fiscal Year 1987 at I-T3 (1986); Office of Management and Budget, Appendix to Budget of the United States Government Fiscal Year 1988 at I-T2 (1987). The House of Representatives recently approved a resolution that would force the EPA to stick to a rigid timetable for distributing funds to schools to clean up asbestos. See House Orders U.S. to Distribute Asbestos Cleanup Funds to Schools, N.Y. Times 11, col. 1 (Feb. 25, 1987).

18 The extent of the remedy provided by the 1984 Act is unclear. The focus of the 1984 Act seems to be limited to the actual removal of asbestos materials from the afflicted schools; it does not seem to contemplate reimbursement for the cost of full restoration to a condition equal to that which would have existed had the materials never been used. Hence, it seems unlikely that a request for replacement of collateral property would succeed. But see 20 U.S.C. \& $4014(\mathrm{c})(1)(\mathrm{C})$, which provides for the restoration of "school buildings to conditions comparable to those existing before abatement activities were undertaken." However, this provision may be construed to limit recovery to the cost of cleaning up postabatement debris or any other costs caused by the actual abatement process.

${ }^{20}$ The 1984 Act explicitly preserves the schools' right to "seek legal redress in connection with the purchase or installation of asbestos materials in schools." 20 U.S.C. $\S 4019(1)$ (Supp. 1985). Even a school receiving grants and loans under the statute may maintain such an action, but the proceeds must be used, to the extent they are sufficient, to repay any 
proves sufficient to meet schools' needs, litigation will remain attractive. School boards may prefer to win a judgment for the full cost of abatement rather than to participate in a program that provides loans for abatement. The availability of legal action may even motivate schools to abate and recover unnecessarily, where they would not have abated at their own expense. In any case, school boards and city and state governments are filing property damage lawsuits against asbestos manufacturers, contractors, and suppliers, seeking billions of dollars in damages.

\section{B. Damage Actions in Contract and Tort}

Breach of warranty is the appropriate contract law action for recovery of abatement costs if such costs are classified as economic losses. ${ }^{21} \mathrm{~A}$ cause of action for economic loss could be brought under the Uniform Commercial Code's implied warranty of merchantability ${ }^{22}$ or its implied warranty of fitness for a particular purpose. ${ }^{23}$ But the maximum four-year statute of limitations imposed by the $\mathrm{UCC}^{24}$ on all actions for breach of sales warranty would bar both claims in the context of economic loss due to asbestos. ${ }^{25}$

Because very few school boards retain any contract rights against asbestos suppliers, the boards must have state tort causes

loans or grants received under the Act. 20 U.S.C. $\S 4017$ (a)(2) (Supp. 1985).

${ }^{21}$ See William L. Prosser and W. Page Keeton, The Law of Torts $\S 95 \mathrm{~A} 680$ (5th ed. 1984) (UCC is exclusive source for liability if claim arises from intangible economic loss); Seely v. White Motor Co., 63 Cal.2d 9, 45 Cal.Rptr. 17, 403 P.2d 145, 149 (1965); MidContinent Aircraft Corp. v. Curry County Spraying Serv., Inc., 572 S.W.2d 308 (Tex. 1978); Price v. Gatlin, 241 Or. 315, 405 P.2d 502, 503-04 (1965); Comment, Manufacturer's Liability to Remote Purchasers for "Economic Loss" Damages-Tort or Contract?, 114 U. Pa. L. Rev. 539, 541 (1966) ("'Economic loss' is defined as the diminution in the value of the product because it is inferior in quality and does not work for the general purposes for which it was manufactured and sold."). But see Santor v. A \& M Karagheusian, Inc., 44 N.J. 52, 207 A.2d 305 (1965) (suggesting economic loss could be recoverable in tort).

22 UCC \& 2-314.

23 UCC \& 2-315.

24 Section 2-725(1) of the UCC stipulates that "[a]n action for breach of any contract for sale must be commenced within four years after the cause of action has accrued," and section 2-725(2) provides that "[a] cause of action accrues when breach occurs, regardless of the aggrieved party's lack of knowledge of the breach. A breach of warranty occurs when tender of delivery is made."

The exceptions to UCC 2-725(2) are not applicable to the asbestos cases. See Cinnaminson Township, 552 F.Supp. at 858.

${ }_{25}$ Because the EPA in 1973 banned the spray application of materials containing more than one percent asbestos, most current claims stem from transactions now more than ten years old. See 1981 Attorney General's Report at 97 (cited in note 6), citing 38 Fed. Reg. 8820 (1973). 
of action if they are to recover. Only in tort may schools take advantage of the "discovery rule," applied by many states, which tolls the statute of limitations until the time the plaintiff actually learned, or through the exercise of reasonable diligence should have learned, of his cause of action against the defendant. ${ }^{26}$ Even with the benefit of the discovery rule, the tort statute of limitations may have run in some asbestos cases. ${ }^{27}$ Schools may not be able to preserve their tort actions by arguing that they knew of the danger but not of the legal remedy. ${ }^{28}$ Many schools' tort claims also may be barred because the vast majority of states have enacted statutes of repose that place an outside time limit on negligence and strict liability claims governed by the discovery rule. ${ }^{29}$ But frequently, courts in asbestos cases have found ways to preserve the tort action in spite of a statute of repose. ${ }^{30}$ Further, some state courts have recently found statutes of repose to be inconsistent with their state constitutions. ${ }^{31}$ In addition, actions based on

${ }^{28}$ See generally Prosser and Keeton, Torts at 165-67 (cited in note 21).

${ }^{27}$ See 1983 Oversight Hearings at 15 (cited in note 7) (statement of Neil G. McBride, Director of Legal Services Program). Schools apparently cannot seek refuge in state statutes exempting governmental bodies from the statute of limitations. County of Johnson v. U. S. Gypsum Co., 580 F.Supp. 284, 288 (E.D. Tenn. 1984); 51 Am.Jur.2d Limitation Of Actions $\S \S 416,421$ (1970). But see Diamond v. New Jersey Bell Telephone Co., 51 N.J. 594, 242 A.2d 622 (1968); 16 Vernon's Tex. Civ. Stats. Ann. Art. 5517 ("The right of the State, counties, incorporated cities and all school districts shall not be barred by any of the provisions of this Title."). Nor would the situation be remedied by having the federal government sue on behalf of the school boards under the 1984 Act. See 20 U.S.C. $§ \S 4017,4019$ (Supp. 1985). A suit brought by the United States on behalf of the school boards would be timely only if a suit brought by the school boards themselves would have been timely. 1981 Attorney General's Report at 199 (cited in note 6).

${ }^{28}$ Compare Damato v. Turner \& Newall, Ltd., 651 F.2d 908 (3d Cir. 1981) (lack of knowledge about legal bases for prospective claims will not toll Pennsylvania statute of limitations), with Sahlie v. Johns-Manville Sales Corp., 99 Wash.2d 550, 663 P.2d 473 (1983) (cause of action accrues with either actual or imputed discovery of the essential elements of the cause of action).

29 Prosser and Keeton, Torts at 167-68 (cited in note 21). Statutes of repose normally run for a longer period of time than the statutes of limitations. General negligence statutes of limitations for personal injury range in duration from one to six years. Id. at $168 \mathrm{n} .31$. In comparison, statutes of repose allow from six to twelve years to bring an action for products liability and from four to ten years to bring an architect-contractor case. Id. at 168 .

so See, e.g. County of Johnson, 580 F.Supp. at 290-92 (examining the state "Products Liability Cap" and holding that school's claim was preserved despite ten-year limit by a clause exempting actions "resulting from exposure to asbestos"); Cinnaminson Township, 552 F.Supp. at 862 (court found that the statute of repose for design defects "was intended to reach only those engaged in the design, planning and construction of improvements to real estate" and not for the benefit of "manufacturers and sellers of products. . . . Product design alone is not enough to trigger the applicability of the statute.") (citation omitted).

${ }^{31}$ See, e.g., Vilardebo v. Keene Corp., 431 So.2d 620 (Fla. Ct. App. 1983); Note, The Constitutionality of Statutes of Repose: Federalism Reigns, 38 Vand. L. Rev. 627 (1985); Thomas J. Dennis, Product Liability Statutes of Repose As Conflicting with State Constitu- 
fraud or misrepresentation survive, and such actions may preserve other claims as well. ${ }^{32}$

Of the two possible tort theories-negligence and strict products liability-negligence claims will be more difficult to maintain, because one element of such claims is foreseeability. It is unclear whether asbestos manufacturers should have known of the risks posed by the relatively low levels of asbestos exposure associated with the use of their building materials at the time those materials were sold..$^{33}$ Even now, these risks have not been well quantified. ${ }^{34}$ In contrast, a strict products liability action is feasible because a plaintiff must show only that a product was defective in a way that made it "unreasonably dangerous." ${ }^{35}$ Building materials containing asbestos were certainly defective in design, in that they possessed defects that later proved unreasonably dangerous. ${ }^{36}$ Thus, products

tions: The Plaintiffs Are Winning, 26 Ariz. L. Rev. 363 (1984); Note, The Constitutionality of Connecticut's Product Liability Statute of Repose, 6 U. Bridgeport L. Rev. 49 (1985). But contrast Braswell v. Flintkote Mines, Ltd., 723 F.2d 527 (7th Cir. 1983) (upholding the constitutionality of Indiana's ten-year statute of repose as applied to asbestos actions).

32 See Hooksett School District, 617 F.Supp 126; County of Johnson, 580 F.Supp. at $290,292$.

ss The potential health hazards associated with the use of materials with asbestos as structural and insulation components of buildings first became generally known in 1977, when researchers observed elevated concentrations of airborne fibers in buildings constructed using such materials. 1983 Oversight Hearings at 28 (cited in note 7). However, the danger of occupational exposure to asbestos has been appreciated since the 1920 s and 1930 s. Borel, 493 F.2d at 1083-84; Bertrand, 529 F.Supp. at 544. The manufacturers are held to the standards of experts, which requires them to keep abreast of scientific discoveries, knowledge, and advances. Borel, $493 \mathrm{~F} .2 \mathrm{~d}$ at 1089 . However, even taking account of such assumed knowledge, some believe that extrapolation of hazards at low exposure levels was not possible until quite recently. See Brief of National Gypsum Company, United States Gypsum Company, and W. R. Grace \& Co. In Support of Motion for Transfer For Coordinated Pretrial Proceedings at 12, In re School Asbestos Litigation, No. 2279-84-NG-8286 (Jud. Panel on Multidist. Litig. Dec. 6, 1984), reprinted in Andrews, Asbestos Litig. Rep. 9413, 9417 (Dec. 21, 1984).

s4 1980 NIOSH Study at 31 (cited in note 7). See also Stanley L. Robbins, Ramzi S. Cotran, and Vinay Kumar, Pathologic Basis of Disease 438 (3d ed. 1984) ("While there is a general relationship between intensity of exposure and the development of asbestos and related lesions (neoplasms) no specific threshold level has been established."); M. David Logan, Asbestos Health Risks: A Continental Conflict, 4 Nat'l Asbestos Council J. 12 (1986) (Canada and the United States disagree on the dangers of asbestos in non-occupational settings.); The EPA Finds Itself Forced to Review its Studies, 2 Asbestos 1 (1986) (EPA admits its health studies were flawed in failing to account for fibre type, size, and industrial process involved); note 118 below.

${ }^{35}$ Restatement at $\S 402 \mathrm{~A}$ (cited in note 3 ). In a products liability action, the focus is on the product, rather than on the manufacturer's conduct.

ss See Prosser and Keeton, Torts at 695, 697, 698 (cited in note 21). Cases involving defects in design generally employ a balancing approach akin to that used in negligence law; liability is premised on a finding that an alternative safer design was feasible. Id. at 699. According to Castleman, safer alternatives to asbestos insulation were available: " $[\mathrm{A}]$ sbestos 
liability claims stand a much better chance of success than negligence claims.

\section{The Border Between Warranty and Products LIABILITY ACTIONS}

Products liability law, which allows recovery without proof of negligence on the part of the defendant manufacturer, reflects a public policy judgment that citizens need broader protection against defective products than warranties afford..$^{37}$ The rationale supporting this public policy is that "responsibility [should] be fixed wherever it will most effectively reduce the hazards to life and health inherent in defective products that reach the market." 38 As the Supreme Court recently explained, concerns about public safety led to a broadening of the manufacturer's duty of care to include protection against property damage in the context of admiralty. ${ }^{39}$

\section{A. Three Current Views}

Courts have split on whether, and under what circumstances, injury to the defective product itself is compensable in a products liability action. ${ }^{40}$ Products liability's overarching goal of public safety should be kept in mind in evaluating the courts' three different approaches.

1. The majority approach. The majority view is that losses resulting from damage to the product itself caused by its failure to function properly can be recovered only through actions in breach of warranty. ${ }^{41}$ These courts rely on the fact that section $402 \mathrm{~A}$ of the Restatement (Second) of Torts ${ }^{42}$ provides for strict liability only in cases of physical injury to person or property, and they therefore hold that the UCC embodies the sole cause of action for cases involving purely economic loss. This approach avoids the

played a limited role in thermal insulation products. . . . [T] he acceptability of alternative materials in place of asbestos has been a fixture in this technology since the 19th century." Barry I. Castleman, Asbestos: Medical and Legal Aspects 296 (1984).

${ }^{37}$ Seely, 403 P.2d at 149.

${ }^{38}$ Escola v. Coca Cola Bottling Co., 24 Cal.2d 453, 462, 150 P.2d 436, 440 (1944) (Traynor J., concurring).

${ }^{30}$ East River Steamship, 106 S.Ct. at 2300.

40 Id. at 2300-01.

4 See, e.g., Seely, 403 P.2d 145; Mid-Continent, 572 S.W.2d at 313. See also cases cited in David E. Bland and Robert M. Wattson, Property Damage Caused by Defective Products: What Losses are Recoverable?, 9 Wm. Mitchell L. Rev. 1, 32-36 (1984).

12 Restatement (Second) of Torts $\S 402 A$ (1977). 
conceptually difficult problem of distinguishing damage caused by an accident to the product itself from that caused by ordinary wear and tear.

The seminal case distinguishing economic loss from physical property damage is Seely $v$. White Motor Co. ${ }^{43}$ In Seely, the court found that the owner of a truck could recover only under warranty for the purchase price and profits lost by virtue of a shock absorption defect that rendered the truck useless in the plaintiff's heavyduty hauling business. However, the plaintiff could, and did, recover in tort for the costs of repair incurred when the brakes failed and caused an accident that damaged the truck. The court stated:

The law of sales has been carefully articulated to govern the economic relations between suppliers and consumers of goods. The history of the doctrine of strict liability in tort indicates that it was designed, not to undermine the warranty provisions of the sales act or of the Uniform Commercial Code but, rather, to govern the distinct problem of physical injuries. ${ }^{44}$

The distinction between economic loss and property damage drawn in the subsequent case law is not clear. Economic loss normally includes the "diminution in the value of the product because it is inferior in quality and does not work for the general purposes for which it was manufactured and sold." 45 The damage measures for economic loss therefore attempt to preserve the benefit of the contracting parties' bargain; damages may be measured by calculating the difference between the value of the product received and the value as agreed upon at the time of purchase. ${ }^{48}$ Or, they may be calculated according to the cost of replacement or repair. ${ }^{47}$ Such a damage measure is consistent with the traditional categorization

4s 63 Cal.2d 9, 45 Cal.Rptr. 17, 403 P.2d 145 (1965). Although Seely is clearly the leading case rejecting recovery of economic loss in tort, the California Supreme Court's treatment of the issue was not necessary to its holding because it had already found for the plaintiff on a breach of express warranty. Interestingly, in this respect, Seely is like Santor, the leading case for the opposite proposition, which also treated the issue only in dicta. See Santor, 207 A.2d at 310-11.

4 Seely, 403 P.2d at 149.

18 Pennsylvania Glass Sand, 652 F.2d at 1169, quoting Comment, 114 U. Pa. L. Rev. at 541 (cited in note 21 ).

48 Pennsylvania Glass Sand, 652 F.2d at 1169 n.13, citing Note, Economic Loss in Products Liability Jurisprudence, 66 Colum. L. Rev. 917, 918 (1966).

17 Pennsylvania Glass Sand, 652 F.2d at 1169 n.13. The court in Pennsylvania Glass Sand pointed out that consequential economic loss includes all indirect loss, such as lost profits or the cost of removal, resulting from the inability to make use of a defective product. 
of removil and replacement costs as economic losses. ${ }^{48}$

In a case in admiralty, the only federal common law of torts, the Supreme Court endorsed the majority view in East River Steamship Corp. v. Transamerica Delaval. ${ }^{48}$ It characterized all types of economic loss, whether slow to develop or due to a "sudden, accident-like event," as "essentially the failure of the purchaser to receive the benefit of its bargain-traditionally the core concern of contract law." "The Court reasoned that the intermediate "sudden and dangerous" test is "too indeterminate to enable manufacturers easily to structure their business behavior." the Court defined "economic loss" to include all types of damage to the defective product itself.

2. The minority approach. A minority of state courts hold that any injury to the defective product itself is compensable regardless of whether it created an unreasonable risk of harm. ${ }^{52}$ These courts reject as arbitrary the distinction between injuries to persons and other property ("physical harm") and injury to the defective product itself ("economic loss").

3. A compromise. Some courts adopt an intermediate view, allowing recovery for economic loss when the public policies of safety and insurance that underlie products liability actions demand that recovery be given. ${ }^{33}$ Drawing on these policies, these courts distinguish between "the disappointed users . . . and the endangered ones." A key distinction in these cases is whether the injury occurred suddenly and in a dangerous fashion.

These jurisdictions make a broader assessment of "the nature of the defect and the manner in which the damage occurred" when considering whether damage to the defective product itself is recoverable in tort." "Defects of quality, evidenced by internal dete-

48 Note, 66 Colum. L. Rev. at 918 (cited in note 46). See also, e.g., Indus. Uniform Rental v. Intern. Harvester, 317 Pa.Super. 65, 463 A.2d 1085 (1983).

19106 S.Ct. 2295 (1986).

so Id. at 2302 . The Court's unanimous decision binds only federal courts deciding admiralty claims, but the reasoning is fully applicable to the state common law of tort.

81 Id. at 2302.

${ }^{82}$ East River Steamship, 106 S.Ct. at 2301, citing Santor, 207 A.2d at 312-13. See also Thompson v. Nebraska Mobile Homes Corp., 198 Mont. 461, 647 P.2d 334 (1983); Mead Corp. v. Allendale Mutual Ins. Co., 465 F.Supp. 355 (N.D. Ohio 1979); City of La Crosse v. Schubert, Schroeder \& Associates, Inc., 72 Wis.2d 38, 240 N.W.2d 124 (1976); Cova v. Harley Davidson Motor Co., 26 Mich.App. 602, 182 N.W.2d 800 (1970).

ss East River Steamship, 106 S.Ct. at 2301, citing Pennsylvania Glass Sand, 652 F.2d at 1173.

s4 Russell v. Ford Motor Co., 281 Or. 587, 575 P.2d 1383, 1387 (1978).

ss The courts hold that these factors indicate whether the defect was "unreasonably dangerous" to other property or persons under $\S 402$ A. See, e.g., Pennsylvania Glass Sand, 
rioration or breakdown, are assigned to the economic loss category, while the loss stemming from defects that cause accidents 'of violence or collision with external objects' is treated as physical injury." "se An accident in which a defective product causes damage to itself or to other property is a form of physical injury ${ }^{57}$ and often is hazardous to persons or property; it is not simply an instance of poor quality or unsuitability of the product to its task. ${ }^{68}$ For example, operation of a defective radiator causes property damage if it results in a fire that destroys the plaintiff's store; but economic loss results if it produces a temperature so uncomfortable that it causes a loss of customer patronage. ${ }^{59}$

Embodying this broader approach, the "sudden and dangerous" test ${ }^{60}$ is based on the rationale that sudden and dangerous accidents pose a greater safety risk to both persons and property than do simple product defects and so are properly actionable in tort. $^{.1}$ For example, in Pennsylvania Glass Sand v. Caterpillar Tractor Corp., ${ }^{62}$ the buyer of a front-end loader sued the manufacturer for repair and replacement costs arising from damage to the loader itself. After four years of use without incident, the machine's hydraulic fluid had caught fire, causing extensive damage.

652 F.2d at 1170 n.14; Vulcan Materials Co., Inc. v. Driltech, Inc., 251 Ga. 383, 306 S.E.2d 253,257 (1983).

s8 Pennsylvania Glass Sand, 652 F.2d at 1169-70.

8z Seely, 403 P.2d at 152. Dean Prosser has stated the principle:

There can be no doubt that the seller's liability for negligence covers any kind of physical harm, including not only personal injuries, but also property damage to the defective chattel itself, as where an automobile is wrecked by reason of its own bad brakes.

William L. Prosser, Handbook of the Law of Torts 665 (4th ed. 1971) ("Prosser Hornbook").

88 Pennsylvania Glass Sand, 652 F.2d at 1169.

${ }^{30}$ Northern Power \& Engineering Corp. v. Caterpillar Tractor Co., 623 P.2d 324, 327 (Alaska 1981), quoting Note, 66 Colum. L. Rev. at 918 (cited in note 46).

oo See Pennsylvania Glass Sand, 652 F.2d at 1174; Vulcan Materials, 306 S.E.2d at 257; Northern Power, 623 P.2d at 328 \& nn. 4, 5.

1 See Comment, 114 U. Pa. L. Rev. at 548 n.54 (cited in note 21). Dean Prosser has commented on the theoretical distinctions between actions in tort and actions in contract:

The fundamental difference between tort and contract lies in the nature of the interests protected. Tort actions are created to protect the interest in freedom from various kinds of harm. The duties of conduct which give rise to them are imposed by the law, and are based primarily upon social policy, and not necessarily upon the will or intention of the parties. They may be owed to all those within the range of harm, or to some considerable class of people. Contract actions are created to protect the interest in having promises performed. Contract obligations are imposed because of conduct of the parties manifesting consent, and are owed only to the specific individuals named in the contract.

Prosser Hornbook at 613 (cited in note 57). See also Bland and Wattson, 9 Wm. Mitchell L. Rev. at 4 n.14 (cited in note 41 ).

e2 652 F.2d 1165 (3d Cir. 1981). 
The plaintiff alleged that the loader was defective because it was not equipped with a fire suppression system or with instructions on the appropriate response to a fire. The court found that

the nature of the defect and the type of risk it poses are the guiding factors. Here, the damage to the front-end loader was the result of a fire-a sudden and highly dangerous occurrence. Moreover, the alleged defect-a faulty design that failed to contain the fire and led to greatly enhanced damage-constitutes a safety hazard that posed a serious risk of harm to people and property. Thus, the complaint . . . appears to fall within the policy of tort law that the manufacturer should bear the risk of hazardous products. ${ }^{63}$

Pennsylvania Glass Sand illustrates that the content of the terms "economic loss" and "property damage" should be informed by the underlying tort law policies governing the recoverability of damages caused by certain defects, and by the agreement of the parties. ${ }^{64}$ Thus, justification for the differential treatment of defects of quality and safety hazards must be sought by identifying and appraising the underlying policy considerations involved in products liability law.

\section{B. Theoretical Justifications for Redressing Defects of Quality Through Contract and Safety Hazards Through Tort}

1. Risk allocation: private agreement versus public regulation. As noted in Seely, ${ }^{65}$ the distinction drawn between property damage recoverable in tort and economic loss recoverable only in warranty reflects a judicial estimation of how risks should be allocated to parties in a sale given three possible techniques: (1) agreement, (2) use of standardized terms that will be inferred (usually from the UCC) in the absence of explicit agreement, and (3) recognition of duties that are mandated by law and that cannot be allocated by the parties themselves. An express warranty falls into the first category, an implied warranty into the second, and liabilities arising from products liability law into the third. Courts decide

es Id. at 1174-75 (citations omitted).

6s See also Cloud v. Kit Manufacturing Co., 563 P.2d 248, 251 (Alaska 1977) ("In their attempts to distinguish between direct property damage and economic loss, the courts should be guided by the existence of, and underlying purposes for, the Uniform Commercial Code warranty actions."); City of Manchester 637 F.Supp. at 650 ("in order to determine in which category the damages alleged here fit, I will turn, as have other courts, to the policy reasons behind the division between 'economic' and 'physical' damages").

403 P.2d at 151. 
which risks are to be allocated by law (rather than by private agreement) and enforce the risk allocations made by each of the three methods.

Because almost every sale involves the allocation of risks, ${ }^{66}$ it is important that these risks be allocated efficiently. Efficient allocation occurs when the party able to handle the risk at the least cost bears the risk. In an ideal market-where rational actors possess perfect information and transactions are costless-sellers and buyers who bargain freely should arrive at the most efficient allocation of risk among themselves. ${ }^{87}$ A rigid rule fixing liability on a particular party may impose needless costs on transactions subject to the rule. ${ }^{68}$ For example, a buyer who already has insurance for bodily injury may not want duplicative coverage; such a buyer would prefer to accept this risk rather than pay a higher price that included some insurance component. Alternatively, the buyer may be able to diversify his own risks, and so may be able to avoid the transaction and overhead costs involved with traditional liability insurance..$^{69}$

However, market defects sometimes create compelling policy justifications for judicial intervention in the allocation process. In reality, buyers may have insufficient information to evaluate risks associated with particular products. Not only may manufacturers be unwilling to disclose information from their greater experience with the product to the consumer, but the consumer may be unwilling to expend any significant amount of time to read such dis-

o6 Risks associated with a sale may include uncertainty of a product's condition, its quality, and its functional characteristics, in addition to risks to third parties arising from product malfunctions. Each of these risks may be allocated differently among the parties according to their positions regarding the particular risk.

or See Ronald J. Coase, The Problem of Social Cost, 3 J.L. \& Econ. 1 (1960). Among the conditions necessary for an ideal market are: (1) perfect information, (2) zero transaction costs, (3) instantaneous equilibrium, and (4) rational actors. See generally Jack Hirshleifer, Price Theory and Applications 8-12, 418-19 (3d ed. 1984). Regarding mass tort claims, an ideal market also would prevent firms from externalizing accident costs through bankruptcy and corporate reorganization. See Robert D. Couter, Defective Warnings, Remote Causes, and Bankruptcy: Comment on Schwartz, 14 J. Legal Stud. 737, 748-50 (1985). Of course, no market is ideal, but the model provides a valuable analytical starting point when analyzing market behavior.

os In excluding economic loss from tort recovery as the federal rule in admiralty, the Supreme Court observed: "[s]ociety need not presume that the customer needs special protection [against economic loss]. The increased cost to the public that would result from holding a manufacturer liable in tort for injury to the product itself is not justified." East River Steamship, 106 S.Ct. at 2302.

CP For a discussion of risk aversion and the allocation of risks, see Steven Shavell, Economic Analysis of Accident Law ch. 8, § A (forthcoming 1987). 
closures or to understand all potential defects. ${ }^{70}$ Finally, the consumer may be in a poor position to assess how much of a reduction in the price of the product he should receive in return for bearing risks himself.

Products liability law thus fixes liability for physical harm caused by a defective product on the manufacturer, the party who has the most information and is thus best able to avoid the harm in the first place. The strict liability rule forces manufacturers to internalize the cost of injuries to third parties, so that overly dangerous products-whose social utility is less than the damage caused by their defects-disappear from commerce. ${ }^{71}$ The manufacturer, with superior information, will evaluate the risk more accurately and so will price the product closer to its true social cost.

In addition, there may be significant savings in information costs through greater efficiency from requiring the manufacturer, rather than each consumer, to evaluate product risks. The most obvious savings would result from the elimination of duplicative efforts on the part of consumers gathering information or testing products. ${ }^{22}$

Information asymmetries and high information costs are important market defects, but the market defect perhaps most often cited in support of products liability is the irrationality of market participants. "Irrational" buyers, it is believed, are either unable to consider and evaluate certain risks of physical harm, or too irresponsible to insure against risks in exchange for a reduction in the purchase price of products they buy. ${ }^{73}$ Courts that subscribe to this

70 For a brief treatment of the nature of customers' true knowledge of product risks, see Shavell, Accident Law at ch. 3, § B.4 (cited in note 69).

${ }^{71}$ See Escola, 150 P.2d at 441 (Traynor, J., concurring): "It is to the public interest to discourage the marketing of products having defects that are a menace to the public. If such products nevertheless find their way into the market it is to the public interest to place the responsibility for whatever injury they may cause upon the manufacturer." That is, by making the manufacturer bear the liability for accidents caused by defective products, the law forces him to set a price adequate to cover their true social cost.

${ }^{32}$ For similar arguments advanced in support of disclosure requirements under the securities regulations, see George J. Benston, Required Periodic Disclosure Under the Securities Acts and the Proposed Federal Securities Code, 33 U. Miami L. Rev. 1471, 1473-74 (1979) ("It is likely that the cost to the corporation of producing such [product] information is less than the aggregate cost to potential and present investors since their efforts are likely to be duplicative.").

${ }^{23}$ The Supreme Court has rejected this model, at least in a purely commercial context, observing that:

Contract law, and the law of warranty in particular, is well suited to commercial controversies [involving economic loss] of the sort involved in this case because the parties may set the terms of their own agreements. The manufacturer can restrict its liability, within limits, by disclaiming warranties or limiting remedies. . . . In exchange, the pur- 
model feel obligated to protect both consumers and injured third parties from consumers' own shortsightedness in the event of an uninsured loss. ${ }^{74}$ These courts fix liability on the manufacturer because he is presumed to be more rational; he will insure against risks and recover the costs through higher prices. ${ }^{75}$

The expansion of products liability theory suggests wide acceptance of this model. Yet the model is overtly paternalistic. By building insurance into the price of goods, products liability does not respect even a deliberate and informed choice not to insure. Such a decision need not be a product of irrationality; instead, it may be the result of risk preference or financial constraints.

The logical consequence of the paternalistic model is that all risks to consumers of products should be assigned to manufacturers by law. ${ }^{76}$ Such an extreme approach forfeits the benefits resulting from voluntary (and thus prima facie efficient) allocation of risk. It is therefore justifiable only where very severe market defects are certain to exist. Where market defects are insignificant or unproven, and the benefits of voluntary allocation are the greatest, bargaining for risk should be preserved. As the following discussion demonstrates, because bargaining for risks relating to the quality and function of goods meets these conditions, these risks should remain in the domain of warranty; and because bargaining for risks relating to sudden and dangerous accidents does not meet these conditions, these risks should be allocated by tort.

2. Two conditions for voluntary allocation of risk.

a.) No significant market defects. As we have seen, informational asymmetry and high information costs are two important examples of market defects. Initially, it may appear that the manufacturer's superiority of knowledge is even greater with regard to

chaser pays less for the product.

East River Steamship, 106 S.Ct. at 2303 (citations omitted). This savings is the value of the risk assumed. To put himself in a similar situation as if an action at law existed for economic loss deriving from a defect in the product, the purchaser could buy insurance with the money saved on the price. Id. at 2302 .

74 In Escola, Justice Traynor apparently intended to protect consumers from their own carelessness and unpreparedness: "Consumers no longer approach products warily but accept them on faith." 150 P.2d at 443. "Those who suffer injury from defective products are unprepared to meet its consequences." Id. at 441. For economists, an "irrational" actor is one who does not try to maximize his expected utility through his decisions.

${ }^{78}$ See Escola, 150 P.2d at 441 (Traynor, J., concurring) ("[T]he cost of an injury and the loss of time or health may be an overwhelming misfortune to the person injured, and a needless one, for the risk of injury can be insured by the manufacturer and distributed among the public as a cost of doing business.").

76 See East River Steamship, 106 S.Ct. at 2302; Grant Gilmore, The Death of Contract 87-94 (1974). 
mundane defects of product quality that cause the product to become inoperable than with regard to defects potentially causing a sudden and dangerous accident. Because product quality defects are much more common, the manufacturer may have collected more statistical data on the probability of such defects.

Nevertheless, the buyer knows two important things about qualitative and functional risks that the manufacturer does not know: (1) the probable extent of the direct loss, which normally will be limited to the cost of replacement, and (2) the probable extent of any consequential damages. Knowledge of consequential losses normally is available only to the customer because only he knows the product's intended use and the probable results of its inoperability. ${ }^{77}$ This knowledge puts the customer in a better position to gauge the loss caused by a qualitative or functional defect. Depending on the magnitude of the probable loss, he can either bargain for a warranty ${ }^{78}$ or protect himself through backup systems. A customer of light bulbs, for example, may be very certain to obtain a powerful warranty and may invest a great deal of time in the purchase decision where the light bulb will be used in, say, a hospital operating room.

Sudden and dangerous defects are quite different. For example, suppose that a light bulb explodes and sets the buyer's house on fire. In such an unpredictable accident, the buyer faces considerable uncertainty in estimating both the probability and the extent of the ultimate loss; indeed, he probably has no more information about the possible extent of the loss than the merchant. In fact, at the time of purchase, the consumer probably does not even know the right questions to ask regarding such accidents. Buyers do consider risks of function and quality; questions such as "Will this product do my job?," "How long will this product work?" and

77 But while the consumer knows most about his own needs, the manufacturer knows most about the product itself. Therefore, in some cases, the simplest way to match the correct product to a task may be for the manufacturer to make available information about the characteristics of his product and let the purchaser decide which is best for his needs. See generally Lewis v. Mobil Oil Corp., 438 F.2d 500 (8th Cìr. 1971). This solution would be unavailable if the manufacturer were forced by law to provide a warranty, because he could not trust the buyer's judgment as to the extent of loss exposure but would have to study all possible intended uses and evaluate such exposure himself. A legal rule that has the effect of always requiring the seller to become expert in all possible intended uses of the product has obvious potential for significant waste.

${ }^{78}$ East River Steamship, $106 \mathrm{~S}$. Ct. at 2303 (recognizing the importance of the buyer's knowledge of the size of potential losses). Even if the seller bears the risk of an economic loss, his liability in contract is. limited by the principle of foreseeability. See UCC § 2-715; Hadley v. Baxendale, 9 Exch. 341, 156 Eng.Rep. 145 (1854). 
"How well?" are central to any purchase decision. But for most products, it is not natural for a buyer to ask "Will this product unexpectedly explode?" This dichotomy justifies voluntary allocation of risks concerning quality or function, and protection of the buyer through products liability from defects resulting in sudden and dangerous accidents.

b.) Large benefits of voluntary allocation of risks. Voluntary allocation of product quality risks should be preserved where the benefits of allowing such allocation outweigh the costs imposed by market defects. Voluntary risk allocation can be an improvement over fixing liability on the manufacturer by law only when buyers and sellers agree that the buyer should bear the risk. In theory, manufacturers should be indifferent to bearing risk since they can simply adjust prices to pass along the costs. ${ }^{79}$ There are three important reasons, however, why the buyer might prefer and should be permitted to bear product quality risks.

(1) Fixed risks and the inappropriateness of risk spreading. When tort law fixes liability on manufacturers for qualitative and functional defects, a manufacturer's inevitable response will be to spread the cost of the risk among all purchasers of his product. Such a rule forces buyers who have great knowledge about their needs and the products that will meet them to insure against a risk they do not face-the possibility that the product will not be fit for their particular uses. Buyers thus have no incentive to acquire information; they are less likely to do preliminary tests with a product, to consider backup systems, or to invest resources to learn more about which products best meet their needs. As a result, some economic losses that are worth preventing are not prevented because the costs of prevention must be borne in full, while the costs of the loss can be largely externalized to the other purchasers of the product.

Similarly, the rule forces buyers who will suffer no consequential losses from inoperability of a product to pay as much for insurance as buyers for whom failure of the product would result in catastrophic, though foreseeable, consequential losses. Some buyers who have no need for insurance may be deterred from buy-

70 Manufacturers gain no competitive advantage from the lower pricing that results from shifting risks to middlemen or final purchasers, because buyers' demand curves will simply be depressed by an amount corresponding to their costs of bearing the risks. For responsible buyers at least, tort remedies available to injured third parties serve to internalize the costs of their injuries to the parties involved in the purchase transaction, and from the third parties' standpoint it should not matter which party bears the risk, as long as they do not seek to avoid it altogether through fraud. 
ing products because of the liability insurance component of the price. On the other hand, buyers with inadequate information, or those who are susceptible to huge losses, may be encouraged to buy the product because part of their insurance cost would be subsidized by low-risk buyers. This state of affairs is akin to the adverse selection that would result if insurance companies charged low-risk insureds and high-risk insureds the same premium.

Allowing a sale-by-sale allocation of qualitative and functional risks will make it more likely that the socially optimal amount of resources be invested in trial runs and research by the prospective buyers. Buyer-specific risk allocations also eliminate the subsidization of high-risk buyers. Therefore, risks of quality and function are most appropriately allocated by agreement of the parties at the time of sale-that is, through warranties.

The UCC permits the merchant and purchaser to negotiate over the terms and extent of the manufacturer's liability for flaws of quality and function. This freedom to bargain would be lost if the manufacturer's liability was to be governed by tort law. The UCC provisions relating to warranties, ${ }^{80}$ limitations on remedies, ${ }^{81}$ limitations on actions, ${ }^{82}$ and notice ${ }^{83}$ would necessarily become irrelevant because a parallel action in strict liability would always be available without these limitations. ${ }^{84}$ These provisions, adopted as statutory law by nearly every state legislature, should not be rendered meaningless by judicial fiat. ${ }^{85}$

In contrast to qualitative or functional defects, defects causing

so UCC \& 2-316(1).

81 Id. § 2-719.

82 Id. \& 2-725.

${ }^{83}$ Id. § 2-607(3)(a).

84 Even if one assumes that a tort action should not be allowed to the same purchaser who explicitly agreed to accept the risk, there remains the problem of giving a tort action to third parties. By filing a tort action, a party not in privity could enjoy the benefit of warranties that may have been expressly disclaimed in the original sale or could maintain an action even though the statute of limitations had run out on the original purchaser. We would have the anomalous situation in which the party not in privity would be owed a greater obligation by the merchant despite his less direct relationship with the merchant than the original purchaser bound by the UCC limitations.

${ }^{88}$ Clark v. International Harvester Co., 99 Idaho 326, 581 P.2d 784, 793 (1978). See also John W. Wade, Is Section 402A of the Second Restatement of Torts Preempted by the UCC and Therefore Unconstitutional?, 42 Tenn. L. Rev, 123 (1974); John W. Wade, Tort Liability for Products Causing Physical Injury and Article 2 of the UCC, 48 Mo. L. Rev. 1, 2 (1983).

Apparently, only one court has taken this point to its logical extreme. See Cline v. Prowler Industries of Maryland, Inc., 418 A.2d 968 (Del. 1980) (refusing recovery in strict products liability action for either personal injury or property damage caused by a defective product, in deference to legislative preemption in adopting the UCC). 
sudden and dangerous accidents justify risk spreading, because as to such accidents the buyer's special knowledge is significantly less relevant. Repeat purchases, for example, are unlikely to inure a buyer to a sudden and dangerous accident if he eventually purchases a single unit that is dangerously defective. Predicting the losses from a sudden and dangerous accident is also much more difficult for buyers since, by hypothesis, customers cannot predict when or how such accidents will occur. When customers misapprehend or erroneously discount risk, there is no reason to assume that a warranty negotiated in the market is a socially desirable allocation of risk. ${ }^{86}$ Because the known risks to buyers in such situations are essentially undifferentiable, a common form of insurance is much more attractive.

(2) Warranty overhead costs. Warranties involve significant overhead costs in addition to the actual repair or replacement costs of the products. ${ }^{87}$ Self-warranting buyers can avoid many of these overhead costs and therefore save more in the reduced price than the value of the warranty.

Any system of insurance, including both warranty and products liability, must limit recovery to the actual value of the loss, ${ }^{88}$ at least in the absence of any egregious behavior that might justify punitive damages. Otherwise, the insured has an incentive intentionally to cause losses. ${ }^{89}$ To avoid this moral hazard, the value of a warranty or tort right guaranteeing the quality or function of a good must diminish as the value of the good itself diminishes over time. Because many overhead costs associated with warranty service-costs of transportation, communication, and spurious claims-remain roughly constant, the proportion of the total cost of the guarantee that corresponds to actual repair or replacement costs diminishes. As the proportion of the warranty costs devoted to overhead increases, at some point a reasonable buyer would prefer to terminate the guarantee in order to save the overhead costs. Thus the buyer has a strong interest in bargaining over the opti-

s6 For a useful discussion of the importance of customer risk perception in justifying product warranties, see Shavell, Accident Law at ch. 3, § B.11 (cited in note 69).

87 Warranty claims usually involve the costs of notifying the warrantor of the claim, transporting the defective product to the warrantor for repair, transporting the repaired product back to the purchaser, and lost use of the product during the repair. Additional costs include processing of spurious claims, damage in transit, and if the repair is unsatisfactory, the costs incurred in making a new claim or seeking legal vindication of warranty rights.

ss This idea is embodied in the insurance law principle of "insurable interest." See generally Robert E. Keeton, Basic Text on Insurance Law § 3.3 (1971).

ss Id. at § 3.1(b). 
mal duration of a warranty in those instances where he decides to pay for one.

In practice, buyers generally do not demand warranties covering most or all of a product's useful life. Most warranties cover only a brief period immediately following the sale, such as 90 days to one year in the case of electronics and home appliances. The warranty periods on more costly goods such as automobiles and computers rarely approach the products' useful lives. One explanation for many buyers' apparent preferences for short-term warranties may be that functional and qualitative flaws in most products appear immediately after use of the product begins, and under the warranty, such products are repaired or replaced. With the lowered odds that a defect will appear after the warranty period, and with the product continuously depreciating in value, the buyer may prefer to bear the risk himself and save the substantial overhead costs of an extended warranty.

While overhead costs are also present when the manufacturer bears the risk of sudden and dangerous accidents, such costs are much more likely to be worth incurring than when the risk is only of economic loss. Because sudden and dangerous accidents threaten harm both to the product itself and to persons and collateral property, the diminishing value of the product itself is less relevant because items of value other than the product itself remain at risk and must be insured.

(3) The moral hazard problem. Unlike negotiated warranties, products liability damage measures do not diminish in value as the product itself ages..$^{90}$ Where a products liability remedy permits replacement of an old, worn product with a brand new one, or where incidental services to honoring a warranty are for some reason valued, there may be spurious claims of defect. For example, if a purchaser could buy a light bulb with a one-year warranty covering repair and replacement, he might be tempted to use the bulb for eleven months and then to break the filament so as to obtain a new light bulb. Even if the warrantor can detect this fraudulent behavior, he must expend resources to litigate or settle the spuri-

9o See Industrial Uniform Rental Company, 463 A.2d at 1091 ("The extension of strict liability to cover economic losses in effect would make a manufacturer the guarantor that all of its products would continue to perform satisfactorily thoughout their reasonably productive life."); Seely, 403 P.2d at 150-51 ("[T]his liability could not be disclaimed, for one purpose of strict liability in tort is to prevent a manufacturer from defining the scope of his responsibility for harm caused by his products. . . . The manufacturer would be liable for damages of unknown and unlimited scope."), citing Greenman v. Yuba Power Products, Inc., 59 Cal.2d 57, 27 Cal.Rptr. 697, 377 P.2d 897, 901 (1963). 
ous claim.

Other types of moral hazards are common to all warranties, even where the warranty payback diminishes as the product ages. For example, buyers under warranty may have incentives to use products excessively, failing to take simple maintenance precautions. ${ }^{91}$ Sellers can only roughly control for overuse and abuse ${ }^{92}$ because of the high costs of drafting and monitoring user-specific contract terms..$^{93}$

In contrast to the moral hazards pertaining to functional and qualitative risk allocations, moral hazards relating to liability for sudden and dangerous accidents are less problematic. First, sudden and dangerous accidents may be difficult or dangerous to fake. A person who might overuse or abuse a light bulb would probably balk at arson, for example. Perhaps more importantly, defects causing sudden and dangerous accidents are easier to verify objectively than alleged failures of expected quality or function.

\section{In Defense of The Sudden and Dangerous Test: Delineating} the Border Between Product Quality Risks and Physical Harm

The inappropriateness of risk spreading, the significance of overhead costs, and the moral hazard problem, as well as improved consumer deliberation, underscore the need for distinctive treatment of risks of economic loss as opposed to risks of physical harm. Voluntary allocation of the risks of qualitative and functional defects produces benefits in the market, while placing the risk of catastrophic accidents on the manufacturer serves other important policy considerations. Predictable rules to discriminate between quality and function risks (economic loss) and other types of risk (physical harm) are necessary to preserve the benefits of both.

While these risks could be classified on a case-by-case weighing of these policy considerations, such a process would be complicated, time-consuming, and costly. Because of this complexity, it would be difficult for market participants to estimate ex ante how the risks would be classified by courts and to adjust their conduct to the legal risk classification. As a result, manufacturers would incorporate an uncertainty premium into the price of products to ensure they were compensated for the risk that a court would hold

21 For a discussion of the moral hazard problem, see Shavell, Accident Law at ch. 8, $\S$ B.3 (cited in note 69 ).

92 UCC $\$ 2-315$ embodies the presumption of an implied warranty, unless excluded or waived under $\$ 2-316$, that goods are fit for the buyer's particular purposes.

os See Shavell, Accident Law at ch. 8, § B.4 (cited in note 69). 
them liable despite the parties' contrary agreement.

To avoid this problem, courts should adopt a simple rule that embodies the general policy concerns. The sudden and dangerous test provides a workable and accurate distinction between accidents that should be actionable in tort and losses that should remain in the domain of warranty law. It focuses on the nature of the accident that caused the loss-or, more precisely, it requires an accident in the conventional sense of the word: something must happen that seriously endangers person or property. The suddenness requirement excludes accidents that were predictable before they began and controllable afterward. The dangerousness requirement includes only those accidents that products liability was designed to treat; that is, it excludes risks unrelated to safety. Consequently, the sudden and dangerous test preserves nearly all the benefits resulting from efficient, voluntary allocation of risk.

Courts applying the test have argued that neither suddenness nor dangerousness alone is sufficient to justify treating the loss in tort. For example, in Northern Power \& Engineering Corp. v. Caterpillar Tractor $\mathrm{Co}^{94}$ an engine failed, resulting in severe damage to the engine itself but no additional injury to persons or property. The court held that claims arising from an accident that was sudden but not dangerous did not sound in tort. ${ }^{95}$ Moreover, the court noted, "[t]he requirement that the loss occur under dangerous circumstances is necessary because ... allowing recovery solely on proof that a defect could endanger persons or property is too speculative." ${ }^{\prime 86}$ If any risks are to be subject to voluntary allocation, the risk that a product will simply stop working without endangering persons or other property, as in Northern Power, should qualify.

Likewise, courts have held that dangerousness alone is not sufficient to bring a loss into tort. In Russell v. Ford Motor Co., ${ }^{97}$ the Oregon Supreme Court observed that physical harm "must be a consequence of the kind of danger and occur under the kind of circumstances ... that made the condition of the product a basis

94 623 P.2d 324 (Alaska 1981).

${ }^{95} \mathrm{Id}$. at 329-30. The court observed:

There is no evidence in the record that such a defect presented a danger to persons or other property and no evidence of violence, fire, collision with external objects, or other calamity as a result of this failure. The engine apparently just stopped operating. [The] loss is, therefore, entirely economic.

${ }^{86}$ Id. at 329 n.1I (emphasis in original). See also Comment, Oregon Adopts the Degree of Danger Test for Strict Liability-The Implied Warranty Alternative, 58 Or. L. Rev. 545, 552 (1980).

${ }_{97} 281$ Or. 587, 575 P.2d 1383 (1978). 
for strict liability. This distinguishes such a loss from economic loss due only to the poor performance or the reduced resale value of a defective, even a dangerously defective, product."98 Risks of defects that merely threaten to become dangerous through continued use are precisely the risks that parties should be free to allocate because they amount only to the risk that the product will have to be repaired or replaced due to inadequate quality or function. In fact, the category of "dangerous but not sudden accidents" may be quite small. The idea of "danger" and, indeed, the very idea of an "accident" naturally imply suddenness, ${ }^{99}$ because if a situation is not sudden, it may be avoidable. For example, recall the person who purchased a light bulb. Suppose that after six months of service, the bulb begins to burn so dimly in the operating room that the owner can no longer safely perform surgery. The danger posed to his patients does not justify treating removal and replacement costs in tort because the danger, being expected, is avoidable.

\section{Abatement in Schools-Tort or Contract Liability?}

Most courts that have been faced with school boards' claims against asbestos manufacturers for the recovery of abatement costs have allowed recovery in tort for damage to the defective product itself-that is, for the cost of replacing the asbestos. ${ }^{100}$ Using the framework developed in part II, this section first criticizes the reasoning of the majority of courts in these cases. Then, applying the "sudden and dangerous" test to claims for recovery of costs of removing asbestos from school buildings, it concludes that because the presence of asbestos constitutes a dangerous but not sudden accident, such claims should not be compensable in tort. Finally, this part demonstrates that the result of applying the sudden and dangerous test in this case is consistent with much of the underlying policy for which the test serves as a proxy.

28 575 P.2d at 1387.

" See Vulcan Materials, 306 S.E.2d at 257 ("An 'accident' should be defined as a sudden and calamitous event which, although it may only cause damage to the defective product itself, poses an unreasonable risk of injury to other persons or property."); Trans World Airlines, Inc. v. Curtiss-Wright Corp., 1 Misc.2d 477, 148 N.Y.S.2d 284 (Sup. Ct. 1955) (recovery denied in tort for lack of an "accident" when defects in airplane engines were discovered before any accident occurred).

${ }^{100}$ See, e.g., City of Greenville, 640 F.Supp. at 564. 


\section{A. Asbestos Abatement Case Law}

Schools have successfully stated tort claims against manufacturers of hazardous building materials, even in jurisdictions that limit recovery in tort to property damage, by characterizing the cost of removing and replacing the materials as physical property damage rather than as economic loss. ${ }^{101}$ The reasoning in these cases reflects misunderstanding of the underlying purposes of products liability law, as well as a failure to appreciate the economic consequences of these decisions. For example, several of the commonly cited opinions are from jurisdictions that explicitly allow recovery in tort for all economic losses. ${ }^{102}$ Such decisions are not relevant to the meaning of economic loss in the jurisdictions that do not allow tort recovery of such losses.

Most courts do not view replacement and removal costs relating to asbestos as economic loss because "asbestos-containing materials have contaminated the building, damaging property and posing a continual hazard to building occupants." ${ }^{103}$ This idea embodies two arguments. The first pertains to collateral property damage, and the second pertains to the creation of a continuing hazard. As discussed below, collateral property that was contaminated before the danger could have been discovered might be recoverable in tort by means of the legal fiction of "sudden realization." ${ }^{104}$ But the latter point that the asbestos itself poses a continuing danger to users of the building does not implicate tort concerns because this danger of physical harm is speculative and avoidable. ${ }^{105}$ It is not relevant that the building materials became

102 See City of Manchester, 637 F.Supp. at 649; Hooksett School District, 617 F.Supp. at 130-31. See generally Terry Morehead Dworkin and Jane P. Mallor, Liability for Formaldehyde-Contaminated Housing Materials: Toxic Torts in the Home, 21 Amer. Bus. L. J. 307, 319-20 (1983).

${ }^{102}$ See Cinnaminson Township, 552 F.Supp. at 857 (expressly decided on the basis of New Jersey's rejection of the doctrine of economic loss in Santor); City of Greenville, 640 F.Supp. at 564, citing the South Carolina case of Terlinde v. Neely, 275 S.C. 395, 271 S.E.2d 768 (1980), as allowing recovery where economic loss alone was suffered.

${ }^{103}$ City of Greenville, 640 F.Supp. at 564. See also City of Manchester, 637 F.Supp. at 649-53; Hooksett School District, 617 F.Supp. at 130-31.

${ }^{104}$ See notes 115-17 and accompanying text below.

${ }^{103}$ In Hooksett School District, 617 F.Supp. 126, the court advanced an argument which might be used to evade disparate treatment of the elements of damage. The court suggested that the asbestos component of the insulation and fireproofing was a defective product that contaminated the insulation and fireproofing in which it was embedded. But this attempt to characterize the asbestos-containing materials as themselves collateral property and only the asbestos component as the defective product simply characterizes the defect as the product. If this approach were to be the general rule, every product failure would be a tort, since one could always characterize whatever part or component failed as a sepa- 
unusable because of a threat of danger rather than through structural deterioration or aesthetic deficiency. Continued use of a product known to be defective will often be dangerous. Merely because it would be unreasonably dangerous for the owner of an automobile to drive his car knowing the brakes have become defective, he has no tort action against his auto dealer for removal and replacement of his brakes.

Courts adopting the contamination theory, and a few that fail even to discuss it, appear to have considered all the elements of damages as if they fell into a single category. ${ }^{106}$ Such courts may have thoughtlessly extended their conclusion regarding collateral property damages to removal and replacement costs of the materials themselves.

The more thoughtful opinion in City of Manchester $v . \mathrm{Na}$ tional Gypsum Co. ${ }^{107}$ explicitly rejected this comment's proposed distinction between elements of damage, arguing that classification as physical harm depends not on "the measure of plaintiff's damages [but on] the nature of the defect and the manner in which the damages occurred." 108 While this court was correct in attempting to look to the nature of the defect and the manner in which the damage occurred, it failed to recognize that the defect was not of the kind which causes sudden harm. The next section demonstrates that such potential future hazardousness is insufficient to allow recovery in tort.

\section{B. Application of the Sudden and Dangerous Test}

The now-familiar risks posed by asbestos are no doubt dangerous; but they are not sudden. They can be avoided either by abatement or by closing down the school entirely.

Asbestos building materials may cause harm by shedding particles into the air that will be inhaled by human beings. ${ }^{109}$ The per-

rate defective product and the remainder of the product as collateral property rendered useless or inoperable by the failure of the component.

${ }^{108}$ See also City of Greenville, 640 F.Supp. at 564; Adams-Araphoe, 637 F.Supp. at 1209; Hooksett School District, 617 F.Supp. at 130-31.

${ }^{107} 637$ F.Supp. 646 (D. R.I. 1986).

${ }^{108}$ Id. at 651 . The court allowed recovery of removal and replacement costs because it found that the hazardous asbestos products contaminated collateral property and that this physical damage "may be measured by the cost of repairing and replacing the asbestos products." Id. The court did note that a legal basis existed to distinguish repair and replacement elements of damage from contamination damage, id. at $652 \mathrm{n} .6$, although it rejected the distinction.

100 The process by which asbestos separates from material and is inhaled is slow and exposure must occur over a fairly lengthy period of time at the low concentrations generally 
sonal injury that results from this inhalation is undoubtedly a basis for a products liability claim. ${ }^{110}$ Yet where this harm is mere expectancy due to the presence of materials containing asbestos, the harm may be avoided.

The possibility that asbestos materials will have to be removed or encapsulated to prevent future damage is not the sort of danger that should provide a basis for a products liability claim. It is analogous to a case in which acoustical tiles fail by discoloring or emitting a terrible (but harmless) smell. ${ }^{111}$ The need to remove these tiles clearly represents economic loss rather than physical harm.

Although the school boards may, however, elect to continue using their buildings with knowledge of the defect, ${ }^{112}$ they can do so only at their own risk. ${ }^{113}$ They would be consciously breaching their duty of care to the students and teachers by exposing them to asbestos. ${ }^{114}$ Because the products liability type risk they face-that of future personal injury to building users-is avoidable, their claims do not satisfy the sudden and dangerous test and therefore should not sound in tort.

School boards may have valid products liability claims for damage to collateral property that was contaminated by asbestos prior to discovery of its dangerousness. The school boards could argue that, while the process by which asbestos degrades is slow and continuous, their awareness of the problem was sudden. ${ }^{115}$ As

associated with schools. See notes 118 and 121 below.

${ }^{110}$ See, e.g., Borel, 493 F.2d at 1087-90.

11 See, e.g., 2000 Watermark Ass'n., Inc. v. Celotex Corp., 784 F.2d 1183 (4th Cir. 1986); 1981 Attorney General's Report at 110 (cited in note 6).

112 While the actual danger created by the relatively low levels of asbestos found in schools-for which bulk sampling confirms the presence of friable asbestos-is unclear, see notes 118 and 121 below, schools have been aware of the problem for some time. See text at note 27 above. To avoid penalizing knowledge, the law applies a "reasonable man" knowledge standard. Hence, a school oblivious to the risk would be in no better position vis-a-vis the "dangerous but not sudden" test than a school which, through reasonable diligence, became aware of the risk.

${ }^{113}$ See Prosser and Keeton, Torts $\S 102$ at 710-12 (cited in note 21 ). The product defect must be a proximate cause of the injury under strict liability. Id. at 710 \& n.2. "[V]irtually all courts have seemingly agreed that the conduct or misconduct of another, including ... the claimant ... may be of such a nature or kind as to constitute a superseding cause." Id. at 710.

116 See Robert D. Lang, The Problem of Asbestos in the Public Schools, N.Y. St. B. J. 18, 20 (Nov. 1984); 1983 Oversight Hearings at 16 (cited in note 7) (statement of Neal McBride, Director, Legal Services Program).

${ }^{116}$ This argument has been successful in insurance cases where strong policy concerns favored recovery for toxic contamination. See Jackson Township Mun. Utilities Auth. v. Hartford Acc. \& Indem. Co., 451 A.2d 990, 994 (N.J. Super. 1982) ("[T] he act or acts [of dumping the pollutants] are sudden and accidental regardless of how many deposits or dispersals may have occurred, and although the permeation of pollution into the ground water 
a result, damage caused by asbestos before its dangerous properties were discovered could be characterized as sudden. Such damage was unpredictable and uncontrollable once it was discovered. Moreover, it was damage dangerous to property distinct from the asbestos itself. Costs relating to replacement of contaminated curtains and carpets, and perhaps a preliminary cleanup of any accumulated loose asbestos fibers, would be recoverable under this interpretation. ${ }^{116}$ However, any costs associated with removal, replacement, or encapsulation of the asbestos materials themselves would not be recoverable in tort, because the future harm they threaten is not sudden. ${ }^{117}$

\section{The Policies Underlying the Sudden and Dangerous Test: The Asbestos Context}

The purpose of the sudden and dangerous test is to classify specific risks as physical harm or economic loss in such a way as to preserve the advantages flowing from voluntary allocation of true product quality risks, while encouraging manufacturers to internalize costs of risks that consumers cannot or will not evaluate. The sudden and dangerous test classifies the costs of asbestos abatement as a form of economic loss. However, it is important to recall that the sudden and dangerous test is justified by three different policy considerations which attempt to account for the great diver-

may have been gradual rather than sudden, the behavior of the pollutants as they seeped into the aquifer is irrelevant if the permeation was unexpected."); Allstate Ins. Co. v. Klock Oil Co., 73 A.2d 486, 426 N.Y.S.2d 603, 605 (1980); Travelers Indem. Co. v. Dingwell, 414 A.2d 220 (Me. 1980).

116 See Walker v. Decora, 225 Tenn. 504, 471 S.W.2d 778 (1971) (cited with approval in County of Johnson v. U. S. Gypsum Co., 580 F.Supp. 284, 292 (E.D. Tenn. 1984)); Hooksett School District, 617 F.Supp. at 130-31.

The 1984 Act does not provide any federal assistance for removal or replacement of contaminated property other than the asbestos itself. The Jackson Township court's interpretation of "sudden," described in note 115 above, has the advantage of dovetailing with the 1984 Act, resulting in liability for these elements of damage the 1984 Act may not cover and only these elements. Liability complementary to the 1984 Act may be the optimal solution to balancing the burden of asbestos harms.

117 Recovery for collateral property through the "sudden awareness" theory of Jackson Township does not provide a basis for characterizing the condition of the asbestos building materials themselves as an accident causing physical harm. The "sudden awareness" theory is, at best, a legal fiction that has never been used outside the insurance context.

Insurance agreements often transfer risk to heavily regulated, public-regarding entities that specialize in bearing risk. In the case of asbestos purchased by school boards, the purchase agreement was a sales contract that was actually intended to transfer risk to the buyer. The purchase price did not include a risk premium to cover abatement costs many years later, and the manufacturer was a purely commercial entity, subject to less regulation in its sales terms, and not particularly expert in bearing risk. 
sity of products sold in the market. Depending on the product, certain factors will weigh more heavily than others. In the case of asbestos building materials, two of the three concerns identified earlier are especially significant: 1) allowing the buyer to take advantage of his superior knowledge of his fixed needs, and 2) avoiding moral hazards.

In the case of asbestos building materials, the first factor, viewed at the time of purchase, tentatively supports voluntary allocation of the risk of asbestos removal and replacement costs. Given the continuing uncertainty about the level of exposure that constitutes a health hazard, it is unclear whether asbestos manufacturers were better able than buyers to evaluate low-level exposure risks. ${ }^{118}$ Thus, the loss-spreading rationale for strict liability does not seem to justify imposition of liability for such risks. ${ }^{119}$ Certainly the asbestos buyers (architects, who were agents of the school boards) knew more than the asbestos manufacturers did about the structures they had designed and the precise use to which they would put the products. If manufacturers are now to be liable in tort, they will, in the future, have to learn in fair detail about the architects' planned use of their products to decide how much to adjust their price to cover their liability. Not only will this likely involve second-guessing the architect, but it will also introduce substantial unnecessary cost to the sale.

The service of removal and reinstallation or of encapsulation is the largest element of expense in abating asbestos building materials. Unlike the value of the product itself, the value of services does not diminish over time. Hence, the second factor, relat-

118 "[T] he exact nature of the dose-response relationships may be subject to considerable debate. This is primarily because of the problems of exposure estimation." 1980 NIOSH Study at 31 (cited in note 7). "In addition, no adequate epidemiolgical information is available on the disease experience of workers exposed below the current standard and followed for a sufficient period to identify long latency effects." Id. at 4. See also Oversight Hearings on Asbestos Health Hazards to Schoolchildren, Hearings on H.R. 1435 and H.R. 1524, before the Subcomm. on Elem., Secondary, and Vocational Educ. of the House Comm. on Educ. and Labor, 96th Cong., 1st Sess. 49 (1979) ("1979 Oversight Hearings"): "[H]ealth effects cannot be unequivocally ascribed to asbestos air concentrations in the range ... found in the . . schools sampled. . . . Furthermore, it is unlikely that a clear association of such levels and the presence or absence of asbestos disease will be made in the foreseeable future. This is the result of the lack of measurements of air concentrations in the past and the need to follow very large populations exposed at lower levels for appropriately long periods of time."

110 Consider also Alan Schwartz, Products Liability, Corporate Structure, and Bankruptcy: Toxic Substances and the Remote Risk Relationship, 14 J. Legal Stud. 689, 729-30 (1985) (rejecting the suggestion that manufacturers can recover the costs of such liability imposition by raising future prices). 
ing to high proportionate overhead costs does not apply in the case of asbestos materials. But, because the service component maintains the value of the warranty over a long period of time, the moral hazard is exacerbated.

As previously discussed, moral hazard, the third factor, is always a problem where insurance is involved. But moral hazards in the asbestos abatement context are especially worrisome. The effectiveness of the necessary diagnostic technology is in doubt. ${ }^{120}$ Since there is no consensus about the levels of asbestos that pose risks worth abating, and because of the very low levels of exposure typically occurring even when asbestos is detected, ${ }^{121}$ the decision as to when abatement should be undertaken and what approach to use when it is undertaken still entails a great deal of subjective judgment. ${ }^{122}$

School boards, however, are likely to play it safe-both to keep the children safe and to protect themselves from potential liability-by undertaking unnecessary abatement if it can be done at someone else's expense. ${ }^{123}$ Similarly, even when some form of abatement is justified, they may elect a more drastic remedy than is necessary: for example, removal and replacement when encapsulation would be adequate or even preferable. ${ }^{124}$ They may carry out

120 Congress has responded to the lack of diagnostic certainty by passing the Asbestos Hazard Emergency Act of 1986. Among other things, the Act requires the EPA to specify asbestos inspection standards and appropriate responses. See note 12 above. In the past, the EPA has directed local educational agencies to identify friable asbestos by visual inspection, sampling, and analysis of samples. See 40 C.F.R. $\$ 763.100$ (1984). The problem with this procedure is that it reveals the presence of friable asbestos but not the existence of airborne particles. The mere detection of friable asbestos in building materials does not indicate that asbestos fibers are being released into the air or, if they are, that they are in sufficient quantity to justify abatement. See Corn, 47 Amer. Indus. Hygiene Assoc. J. at 520 (cited in note 11).

121 The case studies conducted by the Department of Justice concluded that ambient air testing often shows very low exposure levels even in situations in which physical bulk sampling confirms the presence of friable asbestos. 1981 Attorney General's Report at 85 (cited in note 6); 1979 Oversight Hearings at 49 (cited in note 118).

${ }^{122}$ See note 11 above. See also 1983 Oversight Hearings at 42-43 (cited in note 7) (statement of Edward A. Klein, Director, Chemical Control Division, Office of Toxic Substances, EPA); id. at 51 (remark of Rep. George Miller, citing letter from John A. Todhunter, Assistant Administrator for Pesticides and Toxic Substances).

12s See, e.g., 1983 Oversight Hearings at 87 (cited in note 7) (testimony of Council for American Private Education) ("A school undertook an expense of $\$ 66,000$ to replace a ceiling even though it had been assured by a reputable laboratory that the ceiling contained only nonfriable asbestos. Once the presence of "asbestos" became known, public opinion in the school could not tolerate its continued existence."); id. at 2 (statement of Rep. George Miller) (school in Newton, Mass., spent $\$ 1$ million to remove materials that did not contain asbestos).

124 See 1983 Oversight Hearings at 43 (cited in note 7) (statement of Edward A. Klein) 
the operation in a costly manner. ${ }^{125}$ And with so much uncertainty inherent in the schools' decision-making processes, any wasteful or unnecessary actions will prove virtually unassailable by defendants in court.

Significantly, "extra" abatement and removal efforts by schools may not only result in unnecessary or superfluous protection. They may cause affirmative harm. The removal of asbestos materials may fail to reduce levels of suspended dust, or it may even aggravate the problem. Asbestos particles will unavoidably be released into the air when the building materials containing asbestos are damaged during removal or containment. ${ }^{126}$ Moreover, "[ $t]$ hese fibers that pose the danger are microscopic in size and very difficult to detect even with the most highly technical equipment."127

\section{Policy Considerations Peculiar to Asbestos}

Other policy factors unique to asbestos also support classification of abatement costs as economic losses. First, most school boards have already completed abatement by the time they begin to consider legal action against the manufacturer. ${ }^{128}$ Although completion of abatement should not be a factor in deciding individual cases, it is important to note, from a broad public policy standpoint, that in most cases the issue is not whether abatement will occur but merely how the costs will be distributed..$^{129}$

("In cases where the friable material is in poor condition or subject to disturbance, the most appropriate action may be to either remove, enclose, or encapsulate the material."). But in the case of a local Washington-area school, the cheap option of encapsulation was rejected and "the school chose the most expensive solution: removal and replacement." Id. at 88 (statement of Council for American Private Education).

${ }^{128}$ The costs of similar abatement efforts have varied tremendously. See, e.g., id. at 46 (statement of Edward A. Klein), 87 (testimony of Council for American Private Education). 128 Id. at 34 (statement of Edward A. Klein).

${ }^{127}$ Ambach, 474 N.Y.S.2d 244 (finding that plaintiff's asbestos management system entailing use of high efficiency vacuums would not remove these particles from the air).

${ }^{128}$ See notes 13 and 20 and accompanying text above. Of the claims that have been adjudicated to date, nearly all have been claims for costs of abatement already complete. See, e.g., City of Greenville, 640 F.Supp. 559; City of Manchester, 637 F.Supp. 646; Hooksett School District, 617 F.Supp. 126.

129 Two sections of the 1984 Act essentially adopt a policy of not permitting reimbursement of abatement costs if the abatement has been completed prior to the adoption of the statute. 20 U.S.C. $\$ \S 4012(\mathrm{~g})(3), 3605$ (c)(3). In recognition of the limited resources available to meet the problem, Congress apparently intended the law to treat projects that had already been completed differently from those that had not.

Schools may, if they are wealthy, fund abatement from capital funds. For church-related schools, the money can be found within their religious sponsoring organizations. Public school districts may also have the options of fund raising, tax increases, diversion of funding 
Second, to the extent that the need to remove and replace asbestos in the schools ex ante was a "remote risk," appropriate to hold manufacturers liable, because firms will not insure fully against remote risks. Firms insure against products liability only to the extent that they can anticipate the largest expected liability. Thus, firms are bound to be underinsured against liability for remote risks. ${ }^{131}$ When these remote risks materialize and the uninsured products liability costs exceed the firm's wealth, the firm will have strong incentives to avoid paying future claimants by inefficiently spending or liquidating assets. ${ }^{132}$ Bankruptcy law cannot prevent firms from liquidating inefficiently unless the firm is unable to pay off existing claimants, ${ }^{133}$ and managers may believe that it is in the shareholders' best interests to pursue strategies with high current payout. ${ }^{134}$ As a result, imposing liability on manufacturers for remote asbestos risks may not only fail to compensate schools, but it may also generate inefficiencies for future manufacturers who face similar impositions of remote risk liability.

A third benefit of requiring school boards to pay for asbestos abatement is that this approach does not drain the limited funds of the asbestos manufacturers. Several large asbestos manufacturers have gone bankrupt satisfying the claims of victims who have already suffered personal injury from exposure to asbestos and who have no other hope of recovery, ${ }^{135}$ even though most suits are yet

from other public expenditures, or issuance of municipal debt. See 1984 Asbestos Hearings at 8 (cited in note 16) (many school districts can afford to pay 50 percent of abatement costs).

${ }^{130}$ Remote risks may be defined as those risks of great harm of which the manufacturer was ignorant or believed to be unlikely, and for which "research to correct either impression was not cost justified." Schwartz, $14 \mathrm{~J}$. Legal Stud. at 718 (cited in note 119). Certainly, given the uncertainty surrounding the magnitude of risks from exposure to asbestos, at least some of the risks from asbestos are "remote" because they are "more dangerous than a firm would predict if it had done the cost-effective amount of research into safety." Id. at 691 .

${ }^{131}$ Id. at 718-20. Schwartz also notes that even the abolition of limited liability and the extension of successor liability would not create proper incentives to insure. In fact, such departures from corporate law would entail additional shareholder monitoring costs, disincentives to investment, and illiquidity of used corporate assets. Id.

132 Id. at 720-24. Schwartz describes two resource-wasting strategies: 1) liquidating despite the fact that the firm's value as a going concern exceeds liquidation value and 2) undertaking negative net present value projects with large early payouts. Both are consistent with current shareholders' interests and certain aspects of the Johns-Manville bankruptcy. Id. at 724 .

133 Id. at $725-26$.

134 For a discussion of this and related issues, see Douglas G. Baird and Thomas $H$. Jackson, Cases, Problems, and Materials on Bankruptcy 121-22 (1985).

1ss See The Effect of Bankruptcy Cases of Several Asbestos Companies on the Compensation of Asbestos Victims, House Hearings, Subcomm. on Labor Standards of the 
to be filed. ${ }^{136}$ By most estimations, there will not be enough money to pay all the legitimate claims of people who have already suffered indisputable physical injuries. ${ }^{137}$ By allowing school districts to bring a new and questionable class of asbestos tort claims, a class that may dwarf present asbestos claims, ${ }^{138}$ the courts are introducing a new competitor for the already inadequate pool of resources available to compensate asbestos victims.

Finally, in the absence of strong reasons to shift risks, the case for judicial imposition of remote asbestos risks appears to be particularly weak. Obviously, shifting losses creates transaction and litigation costs. These costs should be avoided unless allowing a tort claim advances fundamental goals of tort law. ${ }^{139}$ If asbestos removal and replacement were remote risks at the time of sale, imposing liability on manufacturers does not serve the condemnatory function of tort law, because firms were not aware of the risk and are therefore not morally responsible for failing to eliminate it. ${ }^{140}$ Nor does imposition of liability for these risks effectively spread the losses or serve goals of distributive justice. ${ }^{141}$

Even if these risks were not remote, judicial reallocation of risks seems inappropriate in areas where Congress has acted. Passing three significant statutes in six years, the political branches have demonstrated their recognition of, and desire to solve, the school asbestos problem. These statutes and similar state laws show particular concern for distributive justice.

For those school districts that have insufficient resources to commence abatement without advance financial aid, government help is available on both the state and federal levels. ${ }^{142}$ Because

House Comm. on Educ. and Labor, 98th Cong., 1st Sess. (Feb. 10, 1983); Neil Maxwell, G. Christian Hill, and Raymond A. Joseph, Manville's Big Concern As It Files In Chapter 11 Is Litigation Not Dead, Wall St. J. 1, col. 6, 8, col. 1 (Aug. 27, 1982). A major concern in the bankruptcy reorganizations is providing for future claims. See James S. Kakalik, Patricia A. Ebener, William L. F. Felstiner, and Michael G. Shanley, Costs of Asbestos Litigation (1983); Lewin, N.Y. Times D1, col. 3, D3, col. 1 (cited in note 1).

${ }^{138}$ See, e.g., School Asbestos Litigation, 789 F.2d at 1000 ("To date, more than 30,000 personal injury claims have been filed against asbestos manufacturers and producers. An estimated 180,000 additional claims of this type will be on court dockets by the year 2010."). ${ }^{137}$ See Lac D'Amiante du Quebec, 613 F.Supp. at 1550 ("Total [personal injury] liability projections between the years 1980 and 2015 range from $\$ 7.6$ billion to $\$ 87.1$ billion."). ${ }^{139}$ See Faye A. Silas, Asbestos-free, 71 A.B.A. J. 22 (April 1985); School Asbestos Litigation, 789 F.2d at 1005 .

${ }^{139}$ See, e.g., Schwartz, 14 J. Legal Stud. at 728-29 (cited in note 119) (arguing that tort relief rests on three types of justice: retributive, distributive, and compensatory).

${ }^{140}$ Id. at 733-35.

141 Id. at 729-33.

${ }^{142}$ See 20 U.S.C. $\S 4014(\mathrm{c})(2)(\mathrm{A})$ (making eligibility for, and the nature and amount of 
the 1984 Asbestos School Hazard Abatement Act considers the financial need of the school district in deciding eligibility for aid, ${ }^{143}$ and the form and amount of financial assistance, ${ }^{144}$ the limited federal funds flow to those schools where abatement is contingent on outside funding. Consequently, although the 1984 Act may be grossly underfunded when compared to the total cost of abatement for every school with an asbestos problem, it may work well as a plan to aid the poorest school districts. But, as long as recovery in tort is a possibility, the true effectiveness of this statutory response will remain impossible to assess. Wealthy school boards, those most likely to have completed abatement, have nothing to lose by bringing their cases to court, and may indeed be able to pursue litigation more aggressively. Even poorer school boards will prefer a products liability judgment to some mix of loans and grants.

\section{CoNCLUSION}

Denying recovery in tort for school boards' asbestos abatement costs upholds the broad policy rationales underlying the distinction between economic loss and physical harm. This conclusion follows from necessary principles of bargaining in the market and realistic methods of judicial determination. Denying recovery will not mean that school boards will forego abatement; rather, they will have the proper incentives to draw on all other available resources and disburse the funds efficiently.

The indiscriminate use of asbestos and the harm it has caused are surely one of the greatest tragedies this country has faced in the past decades. But the objective now should be to enforce sound legal doctrine and, in so doing, bring a wide variety of resources to bear on the problem. This is the only way the problem can be wisely managed.

Lindley J. Brenza

financial assistance dependant on financial need); 20 U.S.C. $\S 4014(\mathrm{e})(1)$ (authorizing a loan of up to 100 percent or a mix of loans and grants if financial need warrants it). See also note 16 above.

343 20 U.S.C. $\S 4014(\mathrm{c})(3)$, (d).

1420 U.S.C. $\$ 4014(\mathrm{e})$, (d). 